\title{
Accuracy of serum markers, progesterone and vitamins measurements for early screening of abortions in the eastern region of Algeria (Batna)
}

\author{
Sara Mouffouk, ${ }^{1}$ Mouloud Yahia, ${ }^{1}$ Chaima Mouffouk, ${ }^{1}$ Hanane Boukrous, ${ }^{2}$ Aicha Saaidia, ${ }^{3}$ \\ Fairouz Douha, ${ }^{1}$ Naima Achi $^{2}$ \\ ${ }^{1}$ Laboratory of Biotechnology of Bioactive Molecules and Cell Physiopathology, University of Batna 2 Mustapha \\ Benboulaid; ${ }^{2}$ Laboratory of Biochemistry, Hospital of Batna; ${ }^{3}$ Obstetrics Gynecology Service, Hospital of Meriem \\ Bouatoura-Batna, Algeria
}

\begin{abstract}
Spontaneous abortion is an involuntary interruption of pregnancy before 22 weeks of gestation. According to the Algerian National Institute of Public Health the percentage of women suffering from permanent complications during pregnancy is approximately $15 \%$. The aim of this study is the determination of some biochemical analytes, including folic acid, vitamin B12, alphafoetoproteine, beta human chorionic gonadotropin ( $\beta$-hCG), progesterone and oestradiol ( $\mathrm{uE3}$ ), which are involved in the detection of pregnancy failures. This case-control study was carried out on women in the process of abortion and a control group with viable pregnancies in the East region of Algeria (Batna) during the year 2015. In the present investigation, 69 pregnant women during the first and second trimester were recruited during the first and sec-
\end{abstract}

Correspondence: Sara Mouffouk, Laboratory of Biotechnology of Bioactive Molecules and Cell Physiopathology, University of Batna 2 Mustapha Benboulaid, 53, Constantine Road. Fesdis, Batna 05078, Algeria.

Tel.: +213.777359206.

E-mail: saramouff@yahoo.fr

Key words: Serum markers, progesterone, vitamins (B9, B12), abortion.

Contributions: the authors contributed equally: SM, HA, NA, AS, FD partecipated to the clinical part of the study and followed-up the patients ; SM, CM participated to the editing of the manuscript; MY and $\mathrm{CM}$ revised the manuscript.

Conflict of interest: The authors declare no potential conflict of interest.

Acknowledgments: the authors wish to express their appreciation for the cooperation of all contributed families.

Received for publication: 21 October 2017

Revision received: 18 Dicember 2017.

Accepted for publication: 22 December 2017.

CC Copyright S. Mouffouk et al., 2017

Licensee PAGEPress, Italy

Journal of Biological Research 2017; 90:7151

doi:10.4081/jbr.2017.7151

This article is distributed under the terms of the Creative Commons Attribution Noncommercial License (by-nc 4.0) which permits any noncommercial use, distribution, and reproduction in any medium, provided the original author(s) and source are credited. ond trimesters as cases (with miscarriages) and the control group $(n=69)$ was constituted of women who had normal ultrasound. The average concentration of alpha-fetoprotein is significantly low during the first trimester, but it is very high during the second trimester between cases and controls. The median values of $\beta$ $\mathrm{hCG}, \mathrm{uE} 3$ and progesterone decrease very significantly. The mean concentration of serum folate and vitamin B12 did not change significantly between cases and controls in the first and second trimesters. The results of this study revealed that, spontaneous abortions are associated with changes in serum markers and progesterone, which could form an important part in the early diagnosis of non-viable pregnancies. However, vitamins levels have no significant effects on these pregnancies.

\section{Introduction}

Abortion is one of the main complications affecting women at the beginning of pregnancy, leading to the interruption and the expulsion of an embryo or fetus before 22 weeks of amenorrhea. ${ }^{1}$ There is no systematic diagnosis, but antenatal screening based on the determination of some biological parameters (vitamins, progesterone and serum markers) seems to be interesting in order to identify high-risk pregnancies and participates in the diagnosis of fetal malformations pathologies. Indeed, vitamins are important micronutrients to stimulate the growth and metabolism of the human beings. Some are essential for the synthesis of nucleic acids that are necessary for any cell division, for the formation of body tissues, while others are essential for energy metabolism and gene transcription. ${ }^{2}$ A great increase in vitamin $\mathrm{B}$ requirements is observed in the start of pregnancy, especially vitamin B12 (cobalamin) and B9 (folate). ${ }^{3}$ Cabrol et al. ${ }^{4}$ reporting that one-third of pregnant women have decreased levels of erythrocyte folate during the beginning of pregnancy, this deficiency may be responsible for the anomalies of neural tube closure after conception. From this effect most vitamins can be limiting factors of fetal growth. ${ }^{4}$ In addition, serum markers are biochemical molecules, of fetal or placental origin secreted in maternal serum during pregnancy (Pregnancy associated-plasma protein-A (PAPPA) and free ${ }^{5}$ Alpha-fetoprotein and oestriol). These markers are different from one patient to others depending on the number of weeks of amenorrhea and the status of pregnancy. Several studies have demonstrated the importance of these parameters in the diagnosis of fetal abnormalities and malformations pathologies. ${ }^{6}$ Thus, progesterone is a steroid that plays an important role in the establishment of pregnancy. It prepares and maintains the 
endometrium which will allow the implantation and remove the maternal immune response. ${ }^{7}$ In this context, we are interested in the measurement of the following parameters: folate, vitamin B12, $\beta$-HCG, alphafoetoproteine (AFP), oestradiol and progesterone with a retrospective manner, of hospitalized patients during the first and the second trimesters suffering from complication of pregnancy in order to determine if these parameters contribute really to the establishment of an early diagnosis of non-progressive pathologic pregnancies.

\section{Materials and Methods}

A retrospective study was carried out during the year 2015 on patients hospitalized Obstetrics Gynecology Service of the Hospital of Meriem Bouatoura, Batna, Algeria. The entire selected patients are bleeding at the first or the second trimester of pregnancy.

Participation consent of women was obtained and agreed to collaborate in the study, which was approved by the ethics committee of each participating hospital (Obstetrics Gynecology Service of the Hospital of Meriem Bouatoura and the laboratory of Biochemistry, Hospital of Batna, Algeria). The inclusion criteria for this study were a single non-progressive pregnancy that resulted in cessation, miscarriage or fetal death before 24 weeks.

Patients were identified through survey including: family history, age, date and place of birth, as well as gynecological and obstetric given to the mother (parity and pregnancy outcomes, premature birth and eventual abortions and death in utero). Any previous congenital malformations have been recorded.

The sample included 138 pregnant women, 69 of whom were hospitalized for the first trimester $(n=39)$ and the second one $(n=30)$ pregnancy complications, and a control group of 69 women, with normal and progressive pregnancy.

Vitamins (B9, B12), progesterone and serum markers (AFP, $\beta$ $\mathrm{HCG}, \mathrm{uE3}$ ) are assayed in maternal blood and expressed in MoM (multiple of the median) for each gestational age. Analysis of these parameters was carried out by the immunoassay system (Elecsys 2010 and cobas e 6000) (Roche Diagnostics, Penzberg, Germany).

\section{Data analysis}

Data were analyzed using the one way of variance (ANOVA) a multiple comparison based on a completely random design. $\mathrm{P}<0.05$ were considered statistically significant. Tukey test was applied to determine exactly which treatments were different $(\mathrm{P}<0.05)$. All statistical studies were performed using SPSS Version 20-32bit.

\section{Results}

The analyses of demographic, obstetric and clinical data of all the pregnant women studied (138) are not statistically significant and the results are represented in Table 1.

The serum levels of AFP, $\beta$-HCG, uE3, progesterone and vitamins (B9 and B12) are dosed in the first two trimesters for both groups' patients (cases and controls) and the results are shown in Tables 2-4.

The serum level of alpha-fetoprotein during the first and the second trimesters was $(0.762 \pm 0.431)$ vs $(2.822 \pm 3.293) \mathrm{MoM}$ respectively $(\mathrm{P}<0.05)$. Compared to the control group, themean concentration of alpha-fetoprotein is significantly low during the first trimester, but it became very high during the second trimester.

In addition, the median values of $\beta-\mathrm{HCG}, \mathrm{EU} 3$, progesterone during the first and the second trimester are respectively: $(0.047 \pm 0.071$ and $0.181 \pm 0.22 \mathrm{MoM}, \mathrm{P}<0.05),(0.094 \pm 0.079$ and $0.037 \pm 0.485 \mathrm{MoM}, \mathrm{P}<0.05)$ and $(0.047 \pm 0.071$ and $0.181 \pm 0.220$ MoM, $\mathrm{P}<0.05)$.

The average concentration of seric folate did not change significantly between cases and controls during the first and the second

Table 1. Demographic and clinical data of studied patients.

\begin{tabular}{lcc} 
Demographic and clinical data & $\begin{array}{c}\text { First trimester } \\
\text { (abortion us control) }\end{array}$ & $\begin{array}{c}\text { Second trimester } \\
\text { (abortion vs control) }\end{array}$ \\
Age (years) & $(31.95 \pm 5.78)$ vs $(27.50 \pm 4.54)$ & $133 \pm 6.11)$ \\
Weeks of amenorrhea \% & $5-12(53.1 \%)$ vs $5-12(55.3 \%)$ & $2(0-4)$ vs $0(0-4)$ \\
\hline Number of pregnancy median (min-max) & $1(0-5)$ vs $0(0-4)$ & $1(1-3)$ vs $0(0-2)$ \\
Abortion (number) median (min-max) & $1(0-5)$ vs $0(0-3)$ & $2(0-5)$ vs $1(0-4)$ \\
\hline Number of living children median (min-max) & $1(0-4)$ vs $0(0-4)$ & $0(0-1)$ vs $0(0-1)$ \\
Number of premature children median (min-max) & $0(0-2)$ vs $0(0-1)$ & (4) \\
\hline
\end{tabular}

Table 2. Level of AFP, $\beta$-HCG, oestradiol ( $(\mathrm{EE} 3)$ and progesterone (Mean \pm SD) expressed as MoM in the first trimester.

\begin{tabular}{|c|c|c|c|}
\hline $\begin{array}{l}\text { Parameters } \\
\text { MoM }\end{array}$ & $\begin{array}{l}\text { First trimester } \\
\text { Mean } \pm \text { SD }\end{array}$ & Significance $(\mathbf{P}) *$ & Confidence interval at $95 \%$ \\
\hline AFP & $0.762 \pm 0.431$ & 0.001 & 0.106 to 0.368 \\
\hline$\beta$-HCG & $0.047 \pm 0.071$ & 0.001 & 0.820 to 1.083 \\
\hline $\mathrm{uE3}$ & $0.094 \pm 0.079$ & 0.001 & 0.772 to 1.035 \\
\hline Prog & $0.216 \pm 0.155$ & 0.001 & 0.6513 to 1.884 \\
\hline
\end{tabular}

AFP, alphafoetoproteine; $\beta$-hCG, beta human chorionic gonadotropin; uE3, oestradiol; Prog, progesterone. *, Comparison with the control group: Significant P $<0.05$. 
trimesters and the results are respectively $24.440 \pm 11.421 \mathrm{vs}$ $28.279 \pm 30.422 \mathrm{nmol} / 1, \mathrm{P}=0.990$, for the first trimester and $29.233 \pm 10.976$ vs $31.885 \pm 5.382 \mathrm{nmol} / 1, \mathrm{P}=0.993$ for the second semester. The mean concentration of vitamin B12 has not also varied (Table 4).

\section{Discussion}

Several studies have suggested that fluctuations in serum markers and vitamins could affect fetal development and outcome of pregnancy. ${ }^{8}$ Indeed, our results showed that during the first and the second trimesters, a low rate of $\beta$-HCG which is observed in patients during abortion. It is very important to indicate that these results are in good agreement with the previous studies of Dugoff et al. and Rissanen et al. ${ }^{9,10}$ reporting obviously a low HCG level associated to an increased incidence of spontaneous miscarriage and that extremely low levels of HCG increased the risk of losing pregnancy before 24 weeks.

The same results were previously by Yaron et al. ${ }^{11}$ who reported in their study that an increased risk of spontaneous miscarriage is related to a low concentration of free $\beta-\mathrm{HCG}$. According to Gordon et al., ${ }^{7}$ placental dysfunction resulting from an angiogenesis defect induces a perturbation of $\beta-\mathrm{HCG}$ secretion, which plays a major role in stimulating maternal and fetal steroidogenesis and maintaining corpus luteum. This ensures a good evolution of pregnancy until the seventh week. From the 7 th to the 10 th week of pregnancy the steroidogenesis of the corpus luteum is replaced by the placenta.

The significant decrease of steroid levels reported in our study, is in accordance with data of Bick et al. ${ }^{12}$ who have correlated the decrease in $\mathrm{uE} 3$ with chromosomal abnormalities, anencephalies and fetal death. ${ }^{12,13}$ In most of these pathologies, the level of estriol is reported as being undetectable $(<0.2 \mathrm{MoM})$. However, our results showed abnormally low serum progesterone levels in abortion patients during the two trimesters, which is in agreement with the results of Weissgerber et al. ${ }^{14}$ indicating especially a marked decrease in progesterone. The extrinsic progesterone administration does not extend the gestation period which explains the early onset resulting from abortion. So, progesterone is a good diagnostic marker of non-viable pregnancies as it is the only hormone to maintain the uterine calm. ${ }^{15,16}$ Also a low serum AFP was observed in patients with an abortion in the first trimester. Our results are consistent with several investigations ${ }^{17,18}$ showing the correlation between the low levels of AFP and the spontaneous abortions and the presence of chromosomal abnormalities (aneuploid) such as trisomies and especially when combined with a low levels of HCG ${ }^{18}$ During the second trimester, a significant increase in AFP was observed for affected women compared to the controls. This result is consistent with the literature data, which associate the high abnormal levels of maternal AFP with fetal loss, perinatal death, neonatal deaths, hydrocephalus, diaphragmatic hernias, turner's syndrome, choroid plexus cyst, duodermal atresia, renal pyelectasia and fetal growth restriction. However, moderate increases in AFP levels above the normal value were observed during normal pregnancy in the patient with severe fetoplacental dysfunction explained previously with $\beta$-HCG. The placental damage allows a rapid diffusion of the AFP from the fetoplacental compartment to the maternal compartment, thus inducing an increase in the serum AFP level. Indeed, several studies associate the significant increase in AFP with the risk of pre-eclampsia, intrauterine growth retardation (IUGR), retroplacental hematoma with histologic lesions of type thrombotic and inflammatory placental vessels and death in utero (MIU). ${ }^{19,20}$ Serum concentrations of folic acid and vitamin B12 showed a small decrease in the serum of affected patients. This is in agreement with the results of Hoffman et al. ${ }^{21}$ reporting that low levels of folate did not appear to be associated with complicated pregnancies at risk of abortion in the first or second trimesters.

Table 3. Level of AFP, $\beta$-HCG, uE3 and progesterone (Mean \pm SD) expressed in MoM during the second trimester.

\begin{tabular}{lccc}
$\begin{array}{l}\text { Parameters } \\
\text { Mol }\end{array}$ & $\begin{array}{c}\text { First trimester } \\
\text { Mean } \pm \text { SD }\end{array}$ & Significance $(P) *$ & Confidence interval at 95\% \\
AFP & $2.822 \pm 3.293$ & 0.001 & -2.878 to -0.767 \\
$\beta$-HCG & $0.181 \pm 0.221$ & NS & -0.262 to 1.848 \\
\hline uE3 & $0.037 \pm 0.485$ & NS & -0.092 to 2.017 \\
Prog & $0.170 \pm 0.159$ & NS & -0.225 to 1.884 \\
\hline
\end{tabular}

*, Comparison with the control group: Significant $\mathrm{P}<0.05$.

Table 4. Rate of folic acid nmol/l $($ Mean \pm SD) in the first and the second trimester.

\begin{tabular}{|c|c|c|c|}
\hline Parameters & $\begin{array}{c}\text { First trimester } \\
\text { (abortion } v s \text { control) } \\
\text { Mean } \pm \text { SD }\end{array}$ & Significance (P) & Confidence interval at $95 \%$ \\
\hline Folate $\mathrm{nmol} / \mathrm{l}$ & $24.440 \pm 11.421$ vs $28.279 \pm 30.422$ & NS & -28.835 to 36.508 \\
\hline Vitamin B12 pmol// & $174.490 \pm 83.503$ us $176.942 \pm 65.655$ & NS & 30.2232 to 35.1205 \\
\hline & $\begin{array}{l}\text { Second trimester } \\
\text { (abortion vs control) }\end{array}$ & Significance (P) & Confidence interval at $95 \%$ \\
\hline Folate nmol/l & $29.233 \pm 10.976$ vs $31.885 \pm 5.382$ & NS & -23.1217 to 28.4263 \\
\hline Vitamin B12 pmol/l & $138.122 \pm 55.123$ vs $141.434 \pm 51.756$ & NS & -22.460 to 29.087 \\
\hline
\end{tabular}




\section{Conclusions}

The aim of the present study is to find how we can detect early prevent pathological pregnancies by the determination of some biochemical parameters in the maternal blood such as folic acid, alphafetoprotein (AFP), B-HCG, progesterone and oestradiol. This may be an advance in obstetric and neonatal practices because of the high incidence of these complications. Our results show clearly that (alphafoetoprotein, $\beta-\mathrm{HCG}$, progesterone and oestradiol) could be good markers for the early diagnosis of pregnancies in abortion.

\section{References}

1. Chayachinda C, Thamkhantho M, Bhuwapathanapun M, Srinilta A. Avortement septique: une expérience de 5 ans à l'hôpital Siriraj. J Med Assoc Thai 2012;95:307-12.

2. Costello AM, Osrin D. Micronutrient status during pregnancy and outcomes for newborn infants in developing countries. J Nut 2003;133:1757-64.

3. Ayoubi JM, Hirt R, Badiou W, et al. Nutrition et femme enceinte. J Gynecol Obstet 2012;5:1-14.

4. Cabrol D, Pons JC, Goffinet JF. Traité d'obstétrique. Flammarion, Médecine-Sciences. Paris; 2003.

5. Geyl C, Subtil D, Vaast P, et al. Interprétation des valeurs atypiques des marqueurs sériques. J Gynecol Obstet Biol Reprod 2014;43:5-11.

6. Gagnon A, Wilson RD, Audibert F, et al. Obstetrical complications associated with abnormal maternal serum markers analytes. J Obstet Gynaecol Can 2008;30:918-49.

7. Gordon JD, Speroff L. Handbook for clinical gynecologic endocrinology and infertility. Lippincott: Williams \& Wilkins; 2002.

8. Mobasheri E, Keshtkar A, Golalipour MJ. Maternal folate and vitamin B12 status and neural tube defects in Northern Iran: a case control study. Iran J Pediatr 2010;20:167-73.

9. Dugoff L, Hobbins JC, Malone FD, et al. First-trimester maternal serum PAPP-A and free-beta subunit human chorionic gonadotropin concentrations and nuchal translucency are associated with obstetric complications: a population-based screen- ing study (the FASTER Trial). Am J Obstet Ggynecol 2004; 1 91:1446-51.

10. Rissanen A, Niemimaa M, Suonpää M, et al. Pregnancy-associated plasma protein $\mathrm{A}$, free human chorionic gonadotrophin and nuchal translucency as predictors of miscarriage. Clin Genet 2006;69:287-9.

11. Yaron Y, Ochshorn Y, Heifetz S, et al. First trimester maternal serum free human chorionic gonadotropin as a predictor of adverse pregnancy outcome. Fetal diagnther 2002;17:352-6.

12. Bick DP, McCorkle D, Stanley WS, et al. Prenatal diagnosis of Smith-Lemli-Opitz syndrome in a pregnancy with low maternal serum oestriol and a sex-reversed fetus. Prenat Diagn 1999;19:68-71.

13. Keren DF, Canick JA, Johnson MZ, et al. Low maternal serum unconjugated estriol during prenatal screening as an indication of placental steroid sulfatase deficiency and X-linked ichthyosis. Am J Clin Pathol 1995;103:400-3.

14. Weissgerber TL, Wolfe LA. Physiological adaptation in early human pregnancy: adaptation to balance maternal-fetal demands. Appl Physiol Nutr Metab 2006;31:1-11.

15. Cunningham DS, Brodnik RM, Rayl DL, et al. Suboptimal progesterone production in pathologic pregnancies. JReprod Med 1993; 38:301-5.

16. Daily CA, Laurent SL, Nunley WC. The prognostic value of serum progesterone and quantitative beta-human chorionic gonadotropin in early human pregnancy. Am J Obstet Gynecol 1994; 171:380-3.

17. Muller F, Dreux S, Sault C, et al. Very low alpha-fetoprotein in down syndrome maternal serum screening. Prenat Diagn 2003;23:584-7.

18. Cuckle H. Biochemical screening for Down syndrome. Eur J Obstet Gynecol Reprod Biol 2000;92:97-101.

19. Milunsky A, Jick SS, Bruell CL, et al. Predictive values, relative risks, and overall benefits of high and low maternal serum $\alpha$-fetoprotein screening in singleton pregnancies: new epidemiologic data. Am J Obstet Gynecol 1989;161:291-7.

20. Williams MA, Hickok DE, Zingheim RW, et al. Elevated maternal serum alpha-fetoprotein levels and midtrimester placental abnormalities in relation to subsequent adverse pregnancy outcomes. Am J Obstet Gynecol 1992;167:1032-7.

21. Hoffman ML, Scoccia B, Kurczynski TW, et al. Abnormal folate metabolism as a risk factor for first-trimester spontaneous abortion. J Reprod Med 2008;53:207-12. 